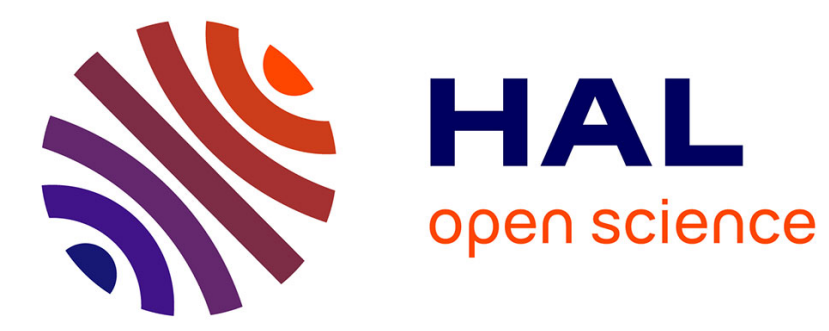

\title{
Impact of the Via Baltica on the Urbanisation in Lithuania by Multi-level Remote Sensing Analysis \\ Sébastien Gadal, Indrè Gražulevičiūtè-Vileniškè
}

\section{To cite this version:}

Sébastien Gadal, Indrè Gražulevičiūtè-Vileniškè. Impact of the Via Baltica on the Urbanisation in Lithuania by Multi-level Remote Sensing Analysis. Environmental Research, Engineering and Management, 2014, 69 (3), pp.17-28. 10.5755/j01.erem.69.3.7361 . hal-01349843

\section{HAL Id: hal-01349843 \\ https://hal.science/hal-01349843}

Submitted on 5 Feb 2019

HAL is a multi-disciplinary open access archive for the deposit and dissemination of scientific research documents, whether they are published or not. The documents may come from teaching and research institutions in France or abroad, or from public or private research centers.
L'archive ouverte pluridisciplinaire HAL, est destinée au dépôt et à la diffusion de documents scientifiques de niveau recherche, publiés ou non, émanant des établissements d'enseignement et de recherche français ou étrangers, des laboratoires publics ou privés. 


\title{
Impact of the Via Baltica on the Urbanisation in Lithuania by Multi-level Remote Sensing Analysis
}

\author{
Sébastien Gadal ${ }^{1}$,Indrẻ Gražulevičiūtè-Vilenišké ${ }^{2}$ \\ ${ }^{1}$ Aix-Marseille Université, Marseille, France \\ ${ }^{2}$ Department of Architecture and Urbanism, Kaunas University of Technology, Kaunas, Lithuania
}

cross $^{\text {ref }}$ http://dx.doi.org/10.5755/j01.erem.69.3.7361

(Received in June, 2014; accepted in August, 2014)

\begin{abstract}
The disintegration of the Soviet Union has totally changed the territorial and urban dynamics of the Baltic countries including Lithuania. Their territorial changes are characterised by an intense process of urban dispersion, suburbanisation, and urban densification. The construction and the renovation of the Via Baltica constitute one of the major elements of the territorial and economic integration of the Baltic States into the European Union. During the middle of 2000', Via Baltica has been and still is a driver of urbanisation caused by the increasing accessibility and automobilisation of the population. The research was aimed at analysing the dynamics of urbanisation in Lithuania in the influence of the Via Baltica in the regional and local contexts. The research has demonstrated that the impact of the Via Baltica on the urbanisation processes measured by remote sensing is more important at the local level. The conclusion was drawn that this transportation corridor should be seen more as a structuring territorial vector of the general process of urbanisation and metropolisation of Lithuania.
\end{abstract}

Keywords: post-Soviet transformations, remote sensing, landscape management, Via Baltica, Lithuania

\section{Introduction}

The collapse of USSR (the Union of Soviet Socialist Republics) has brought many socio-political, socio-economic, socio-cultural and environmental challenges as well as opportunities in the fields of environmental research, landscape research, regional development and urbanism. Socio-political, socioeconomic, socio-cultural, and environmental changes in the post-Soviet states attract considerable interest. However, as J. P. Ferrier (1993, 1998), D. Polanska (2008) note, the urban areas are the mirrors of change in the societies. Thus, the increasing attention is devoted to the regional development (Melnikas 2005) and urban dynamics in the post-Soviet space including Central and Eastern Europe (MurzynKupisz and Gwosdz 2011; Scott and Kuhn 2012) and the Baltic states (Bardauskiene and Pakalnis 2012). The transformations after the declaration of the independence of the former Soviet republics, including Lithuania, which is the object of this research, can be characterised by the territorial dynamics with an intense process of territorial dispersion during the 1990' of the pre-existing urban settlements, the densification of urban areas, the growth and the emergence of suburbs during the 2000' (Gadal 2011a; Bardauskiene and Pakalnis 2012). The post-Soviet territorial transformations were related not only with the urban settlements, but also with communication and transport corridors. The development, changes and impacts of the road network in the Baltic region is an object for considerable attention. It includes sustainability (Serry 2010), management (Rodzik and Quieroz 2010), restructuring (Ojala and Quieroz 2003), pollution (Baltrenas 2004) and safety issues (Lama et al. 2006). The acceptance of the Baltic States into the European Union (EU) in 2004 caused the need to connect to and integrate into the European territory and the European market. The reorientation of the spatial infrastructure of communication towards the South imposed the shift from the East-West network structural territorial integration of the Soviet period to the North-South direction and the European networks. 
The urban dynamics and reorientation/ development of the transport routes in the post-Soviet space cannot be viewed in isolation. The connections and transport routes influence the urban dynamics of countries/ regions and encourage analysis of the interaction of socio-political and socio-economic changes, shifts in importance of transportation corridors and the dynamics of urbanisation. In this research, Lithuania (in the regional context) and the Lithuanian segment of Via Baltica - the Warsaw-Tallinn tract of the European route E67 - have been selected to illustrate these interconnections. Despite the low standard of facilities (Gadal 2012), the Via Baltica became the major axis of exchanges between the Baltic region and Central Europe. The construction and renovation of this route during the beginning of the 2000' have driven the population mobility and the process of urban growth with the suburbanisation and the settlement dispersion.

The aim of the research was to analyse the types of urbanisation in Lithuania in the influence of the Via Baltica in 2000 - 2012 in the regional and local contexts of landscape management and in the global context of metropolisation.

\section{Methodological approaches}

The analysis of the urban changes induced by the Via Baltica is based on the remote sensing data. The aerial photographs, remote sensing and satellite images had substantially changed the fields of landscape research and management. Many landscape studies based on aerial views and satellite images conducted using Geographical Information Systems and other software had emerged. Contemporary urban planning and landscape management also increasingly require data on changing land use, urban sprawl and the environment (Nigam 2000) at various levels. The volume of such analyses is constantly growing and the principles for such analyses are being developed (Giri 2012). Advanced technologies allow mapping the multiple layers of landscape information, distinguishing the rapidly changing land uses (Ramachandra et al. 2014). A. Ode et al. (2008) suggest combining landscape photographs, observations on site, orthophotos, land cover data in landscape analysis. Literature review has demonstrated the substantial experience in this field of research: analysis of urban expansion (Bhattaa et al. 2010), metropolisation (Abrantes et al. 2005;
Gadal 2003; Gadal 2011a), rural-urban interface (Nigam 2000; Antrop and Van Eetvelde 2000; Gadal 2010), and transportation corridors (Sohn et al. 2005; Wang et al. 2008; Wu and Hu 2010; Zielinski and Iwanowski 2011) etc. Considering the existing experience, this research was based on the integration of several tools and data sources on different levels including observations on site, satellite data and land cover data as well as analysis of urbanizationtransportation corridor links at different levels: regional and local. The remote sensing approach provides a measure of the forms and types of urbanisation within the Via Baltica from 2000 to 2012 in the regional context of urban growth. Two types of satellite data have been used: Landsat 5 TM and Landsat 7 ETM+ for analysis of the urban changes at the local level, and the DMSP series for modelling of the urban changes at the regional level. The use of these space systems of Earth observation with different spatial and spectral characteristics (cf. 2.1.) enables modelling of the urban transformations at two geographic levels: the regional level with DMSP OLS (Operational Linescan System) and the local level with Landsat 5 TM and Landsat 7 ETM+ satellites. Thus, the research approach can be referred to as multi-level remote sensing analysis of urbanisation processes with the analysis of the geographic space at the geographic levels and the use of two different satellite platform systems (Manchanda et al. 1983; Wheeler and Ridd 1985; Short 2005; Gadal, 2006; Andersen et al. 2011).

\subsection{Satellite data}

The monitoring of the urbanisation by remote sensing on the Via Baltica is based on the use of Landsat series thematic mapper and enhancement thematic mapper data with a spatial resolution of 900 $\mathrm{m}^{2}$ covering a surface of $32375 \mathrm{~km}^{2}$ on a period of 25 years from 1987 to 2012. Landsat 5 TM and Landsat 7 ETM+ enable analysis of the process of urbanisation and territorial change at the local level by the spatial resolution of $30 \times 30$ meters, and regional level with the surface of $1960000 \mathrm{~km}^{2}$ covered by the Defence Meteorological Satellite Program (DMSP). The use of DMSP OLS series images taken by night gives a regional mapping of the spatial repartition of the major urban areas, the surface covering all the Baltic States and Europe and the spatial resolution of $7,29 \mathrm{~km}^{2}$ detecting large urban territories.

Table 1. Spatial and spectral characteristics of Landsat and DMSP series

\begin{tabular}{|c|c|}
\hline \multicolumn{2}{|c|}{ Spectral and spatial characteristics of Earth observation systems platforms used } \\
\hline $\begin{array}{l}\text { Landsat } 5 \text { TM } \\
\text { (Thematic Mapper) }\end{array}$ & $\begin{array}{l}\text { Spatial resolution: } 30 \times 30 \mathrm{~m} \\
\text { Spectral resolution: band } 1[0.45-0.52 \mu \mathrm{m}] \text {; band } 2[0.52-0.60 \mu \mathrm{m}] \text {; band } 3[0.63-0.69 \mu \mathrm{m}] \text {; band } 4 \\
{[0.76-0.90 \mu \mathrm{m}] \text {; band } 5[1.55-1.75 \mu \mathrm{m}] \text {; band } 7[2.08-2.35 \mu \mathrm{m}]}\end{array}$ \\
\hline $\begin{array}{l}\text { Landsat } 7 \text { ETM+ } \\
\text { (Enhanced Thematic } \\
\text { Mapper) }\end{array}$ & $\begin{array}{l}\text { Spatial resolution: } 30 \times 30 \mathrm{~m} \\
\text { Spectral resolution: band } 1[0.45-0.515 \mu \mathrm{m}] \text {; band } 2[0.525-0.605 \mu \mathrm{m}] \text {; band } 3[0.63-0.69 \mu \mathrm{m}] \text {; band } \\
4[0.76-0.90 \mu \mathrm{m}] \text {; band } 5[1.55-1.75 \mu \mathrm{m}] \text {; band } 7[2.08-2.35 \mu \mathrm{m}]\end{array}$ \\
\hline $\begin{array}{l}\text { DMSP F-10 / F-15 } \\
\text { OLS } \\
\text { (Operational } \\
\text { Linescan System) }\end{array}$ & $\begin{array}{l}\text { Spatial resolution (smooth mode): } 2.7 \times 2.7 \mathrm{~km} \\
\text { Spectral band: "temperature range of } 190 \text { to } 310 \text { Kelvins in } 256 \text { equally spaced steps. Onboard } \\
\text { calibration is performed during each scan. Visible pixels are relative values ranging from } 0 \text { to } 63 \\
\text { rather than absolute values in Watts per } \mathrm{m}^{2} \text { " (NOAA, 2014). }\end{array}$ \\
\hline
\end{tabular}




\subsection{Recognition and extraction of urban areas}

\section{Landsat 5 TM /7 ETM+ images}

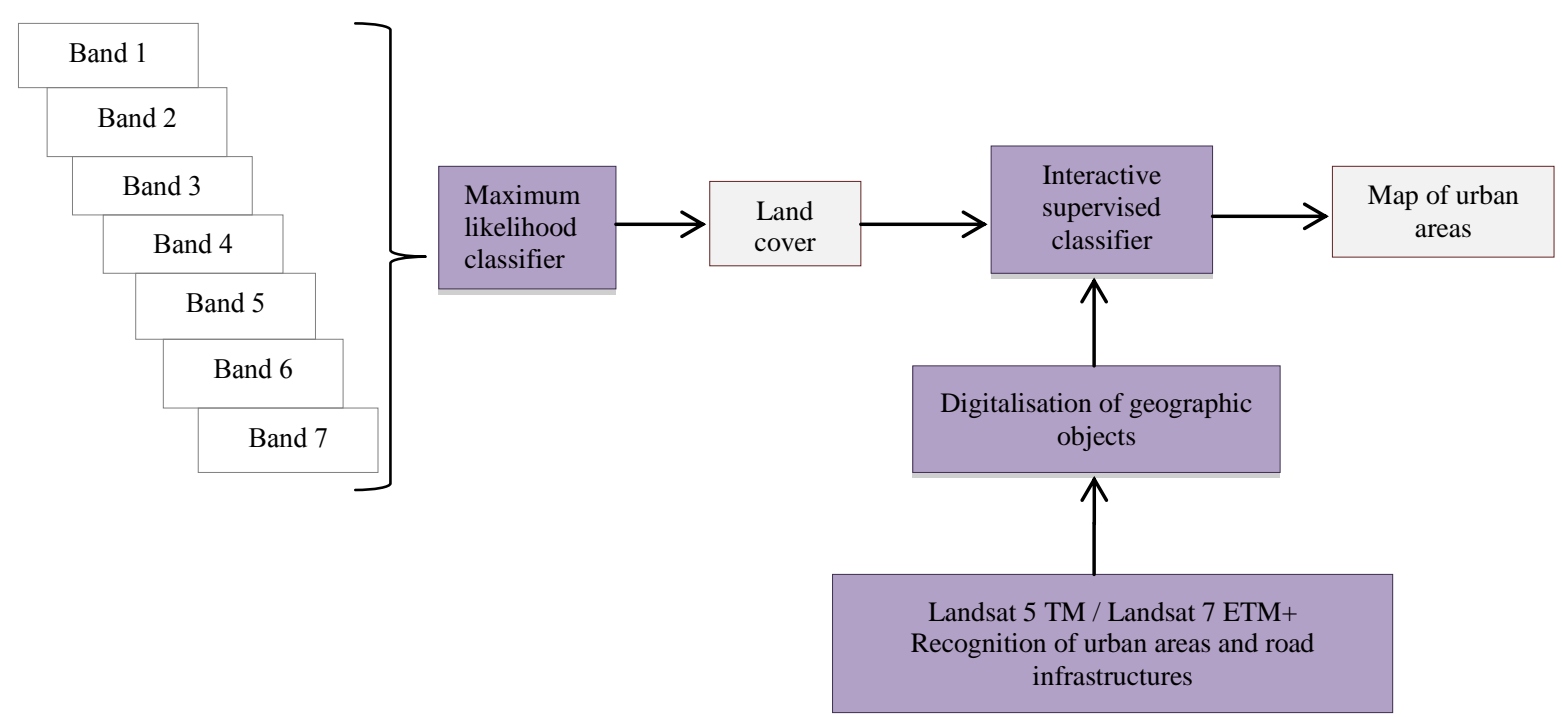

Fig. 1. Chain of image processing with multi-spectral Landsat series data (Gadal 2012)

The generation of the urban land covers' change modelling with Landsat data series is based on the merging of two methodological image processing approaches based on different classifications methods: maximum likelihood classifier for the automatic image processing and the interactive supervised classifier for the supervised classification. The integration of all the spectral bands for generating land cover maps with the maximum likelihood classifier takes all the biophysical characteristics of the landscape, improving the accuracy of the recognition of objects (buildings, roads, forests, etc.) and generation of maps. The urban objects are characterised by a large panel of spectral resolution because of the different urban landscape materials. Land cover maps created are reintroduced in the image processing chain for increasing the level of detection and decreasing the error rate of missclassification. The accuracy of the recognition of urban areas is improved on the land cover maps created with maximum likelihood classifier by the application of oriented object approach based on the visual interactive recognition of urban objects: digitalisation of the recognised urban areas, integration of the detected objects in the classifier for the detection, extraction and automatic mapping of the urban areas recognised.

\subsection{Urban land cover change model}

The cartography of the urban land cover change is made from a temporal analysis of the urban areas recognised and extracted by the image processing methods based on the exploitation of the spectral responses of the urban objects in the visible and infrared spectral bands 1, 2, 3, 4, 5 and 7 with Landsat series (Fig. 1.), and visible near infrared band with DMSP series. The urban land cover change cartography is made by the merging the digital maps of the urban areas generated each year from 1987 to
2012 (Fig. 4; Fig. 5; Fig. 7). The method of fusion modelling of the urban growth is based on the Land Change Modeler using the arithmetic calculus image differentiation between each date (Mas et al 2014).

\section{Regional analysis: the emergence of metropolisation}

Since the collapse of the USSR, many changes in the Baltic States took place including the transformation of political and economic regime, the lack of strategic planning and the integration in the EU. These changes affected the social, environmental and spatial dynamics as well as territorial change during the last twenty years: the return of land to the owners, privatisation of property, the abandonment of surplus farmland, expansion of forests, the migration of young people to the cities, massive emigration (in 2012 alone, 41100 persons emigrated from Lithuania (Oficialiosios... 2014)), the ageing of the population, the collapse of rural infrastructure and the decay of old houses and rural buildings (Bell et al. 2008; Kuemmerle et al. 2010; Bardauskiene and Pakalnis 2012), deindustrialisation, the uneven regional development, the urban expansion, the suburbanisation, the gentrification. Part of these societal and geographic changes can be associated with the emergent process of metropolisation at the regional and local levels.

The geographical and societal process of metropolisation globally transformed the structures of territories, the population lifestyles, planning, urbanism, and economies since the 1970'. The process of metropolisation is characterised as the geographic face of globalisation and of the transformation of human lifestyle (Gadal 2011a). Moreover, the result of globalisation of world economies is concentration of economic power in the limited number of World cities (Abrantes et al. 2005). S. Kratke (2007) sees 
metropolisation and globalisation as the main trends of spatial development in Europe. P. Abrantes et al. (2005) distinguish several features of metropolisation:

- Development of the services sector - economies of agglomerations favour the concentration of executives, international companies etc.

- Distortion of the urban hierarchies and the reinforcement of the higher levels of the urban network.

- Inner spatial rearrangement and fragmentation of cities as an opposition to coordination and planning of urban areas. Actually, the metropolised territories are most often spatially multi-polarised urban discontinuities, segregated socially and functionally. This type of territorial structure covers large spaces at the regional level (Gadal 2011a).

S. Kratke (2007) underlines several aspects of metropolisation relevant to this study. According to him, the EU aims at creating a trans-nationally interlinked economic and institutional space, an economic block globally competing with other large economic blocks in North America and Asia. The economic development centres of this bloc - the urban agglomerations and metropolitan regions - will function at the regional level and at the same time will be the prime nodes of Europe's integration in the global economy. However, as S. Kratke (2007) notes, the increasing concentration of economic development in urban agglomerations and metropolitan regions is one of the reasons of the increased regional disparities and uneven regional development in Europe. Not only underdeveloped rural regions, but also many of the less dynamic urban regions of Europe are threaten to experience disadvantages and decline if they are not economically linked with important Europe's urban agglomerations and metropolitan regions. Considering these links between the economic connections and spatial development, this research focuses on the role of transport corridors in metropolisation. In this case, the Baltic States after the collapse of USSR and integration into the EU experience the shifts in the economic interests and in the importance of transportation routes.

\subsection{Territorial integration: reorientation of the transportation network}

Two major historical communication axes in the contemporary Lithuanian territory linking it with surrounding regions reflect the geopolitical situation of the country and relatively recent socio-political and socio-economic transformations after the collapse of the USSR (Fig. 2.). The Klaipeda-Vilnius-Kaunas transportation corridor linking the three major historic cities of the country is the structural axis of development in Lithuania since the Soviet period. This strategic development corridor links Minsk, Moscow, Kiev and Odessa (Black Sea). With the collapse of the USSR, Lithuania has inherited a part of the West hinterland of the former USSR. It determines the economic geopolitics of the Lithuanian Republic with its neighbours, particularly with the Republic of Belarus. In 1991, both freight and passenger volumes rapidly decreased due to the overall economic downturn and the pre-independence volumes of road transport were achieved only in late 1990' (Ojala and Quieroz 2003). The importance of territorial organisation of former Soviet Lithuania as well as of East-West development corridor, the lack of post-independence strategic politics of territorial development, as in Latvia, maintains economic market geographically, structurally and spatially dependent from the Russian Federation and the Commonwealth of Independent States (CIS) countries. The country struggles to shift or diversify its economic networks: $40 \%$ of the Lithuanian economy is dependent on the Russian market (Gadal 2011). The transit function for trade with Russia transport of mainly CIS raw materials to Western markets and Western manufactured items to CIS countries still remains very important for all Baltic States in terms of the economic activity that it generates. (Ojala and Quieroz 2003; Kovacs and Spens 2006).

The urgent need to complement and to reorient the trade directions/ transport patterns forced the Baltic States to finance many of the major transport sector projects with exclusive or partial funding from the international financial institutions or from the EU (Ojala and Quieroz 2003) including the North-South transport corridor stretching in the territory of Lithuania. This second major corridor of development, which also has historical roots, has shaped relations and part of the Lithuanian economy since the Middle Ages, the Berlin-Warsaw-KaunasRiga-Tallinn route, the ancient Via Baltica, is one of the strategic corridors of development officially recorded and supported by the EU (Gadal, 2011). 


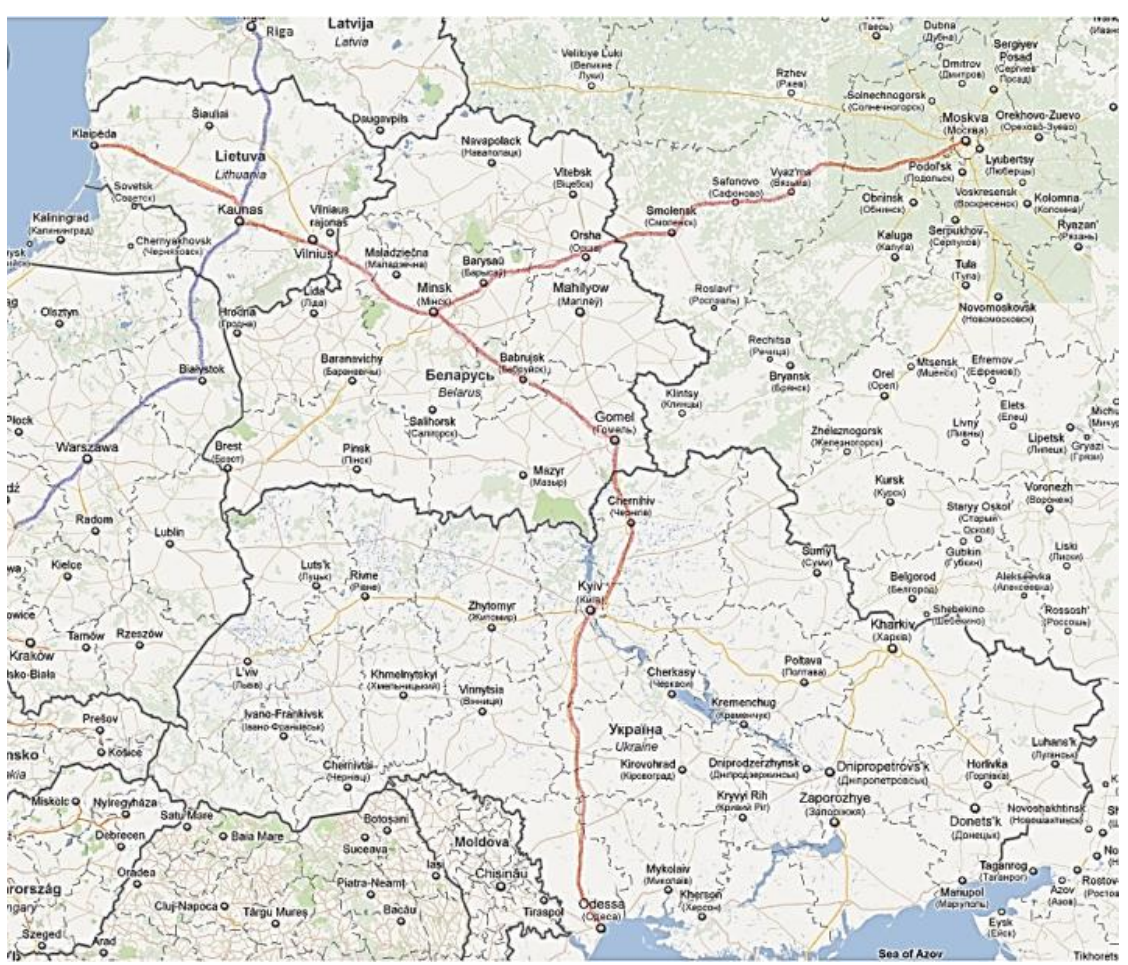

Fig. 2. Trade corridors in Lithuania: East-West - exchange corridor set up under the USSR, phase of reactivation along an axis Klaipeda via Odessa-Kiev and Minsk (trans-Asian trade) (red lines); North-South - Riga-Kaunas-Warsaw - the Via Baltica axis of development planned by the EU (Prague-Warsaw-Kaunas-Riga-Tallinn-Helsinki) (blue lines). Source: Google Maps, August 18 ${ }^{\text {th }}, 2011$ and field surveys in 2006, 2009, 2011

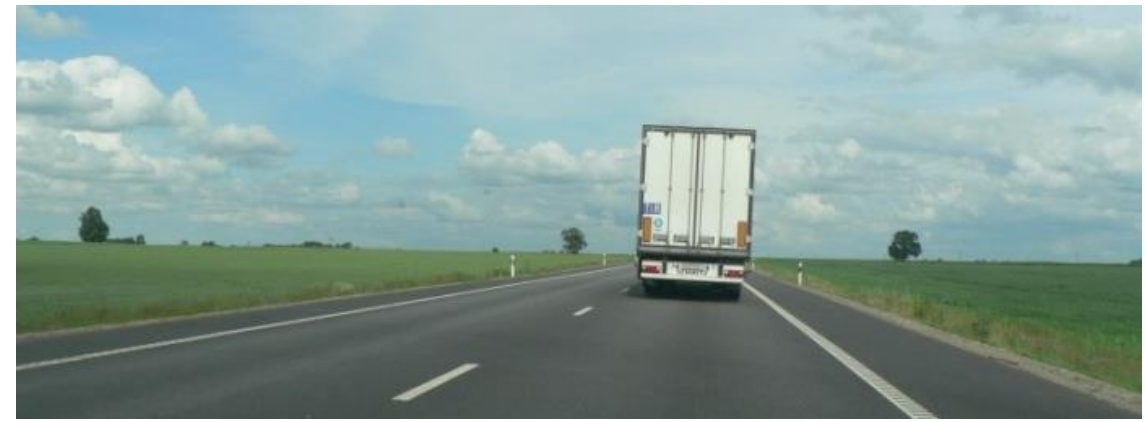

Fig. 3. View of the Lithuanian tract of the Via Baltica in the segment running from Kalvarija via Marijampole to Kaunas. Photograph by I. Grazuleviciute-Vileniske

The Via Baltica project is constantly expanding. Already in 1994, the international agreements have been made to develop the pan-European network of roads from Warsaw in Poland, via Lithuania, Latvia and Estonia to Helsinki in Finland. The Lithuanian tract of the Via Baltica route runs from Kalvarija via Marijampole to Kaunas (Fig. 3.), from there to Panevezys, and via Pasvalys is stretching forward to Salociai at the border with Latvia. The Via Baltica today is one of the most significant transit arteries of the country and its importance is growing. In 1993, 470 vehicles (including 140 trucks) per twenty four hours used to cross the Polish - Lithuanian border, whereas in 2012, it was already 8429 vehicles (including 5842 trucks) (Giriunaite 2013). Its importance to the intensification of trade for the European Union and particularly for Germany, Poland, Latvia, Estonia, and Finland is as crucial as the Rail Baltica project. The high concentration of the freight forwarding industry in the Baltic States and reorientation or transport routes in Lithuania makes it an intersection of East-West and North-South trade routes encouraging analysis of the influence of these processes of urbanisation on the regional scale.

\subsection{Regional transformations}

P. Abrantes et al. (2005) distinguish the distortion of the urban hierarchies and the reinforcement of the higher levels of the urban network - i.e. the emergence of the urban agglomerations and the metropolitan regions interlinked and functioning not at the national but at the international and global levels - as one of the features of metropolisation. From one point of view, such agglomerations can be beneficial for national economy and prestige, from the other - they cause uneven regional development, the decline of settlements in the disadvantaged areas and generate substantial impacts on the environment and landscape quality in the zone of their influence. The urban growth measured by remote sensing within the Via 
Baltica since the end of the Soviet period allows comparing this situation in Lithuania and Latvia and evaluating the influence of different spatial structures on the regional transformations induced by the Via Baltica transport corridor (Fig.4.). The question may be asked: whether the Via Baltica became the axis of urban development and stimulus for metropolisation or just a transport corridor.

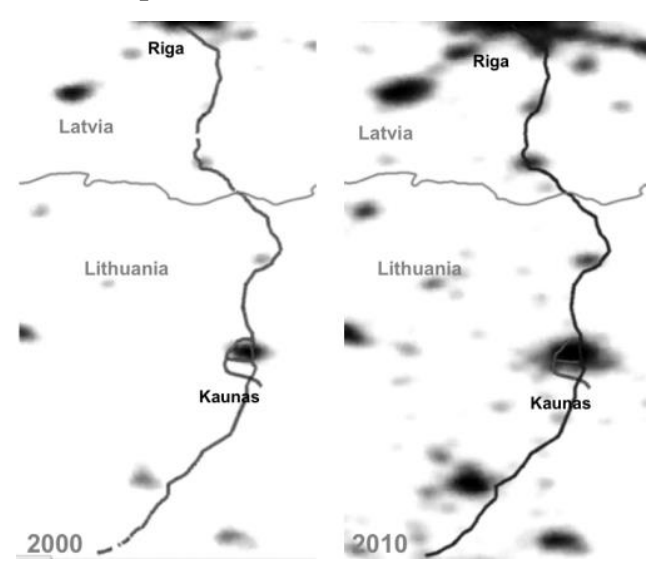

Fig. 4. Regional growth of urbanisation within the Via Baltica (2000-2010) by DMSP OLS (Gadal 2012)
The analysis has demonstrated that in Latvia, in regard to the regional level, the Via Baltica is a transportation infrastructure reinforcing the dynamics of urban extensions and dispersion in the hierarchic centralised organisation of the urban Latvian territory. The Via Baltica is the major infrastructure of communication linking the neighbouring towns to Latvian capital Riga in a radial spatial organisation. It can be considered more as a corridor of urban development (Fig. 4.) and the city of Riga more as an urban agglomeration, metropolised area and international economic centre distorting urban hierarchies and causing uneven regional development. Meanwhile in the territory of Lithuania, according to the territorial organisation, the Via Baltica impact on the urbanisation is more difficult to measure. The dense and dispersed territorial framework and network of medium and small towns/ villages seems to limit the Via Baltica impact on the territorial organisation (Fig. 4.) causing more even regional development. The urban growth since the end of the Soviet period is observed in the large part of the country (Fig. 4., Fig. 5.).

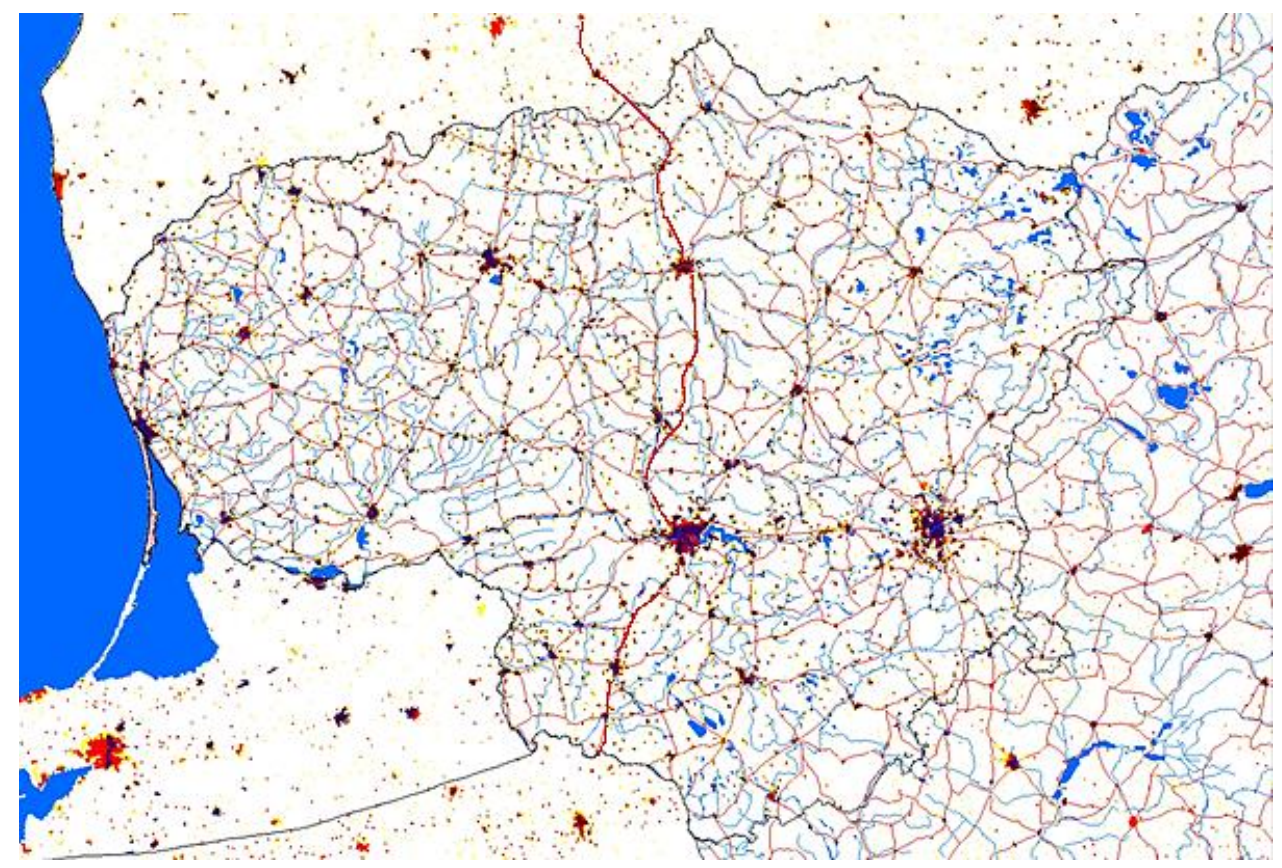

Fig. 5. The Via Baltica (red solid line) and urbanisation patterns (urban areas in 1989 - black, urban areas in 2000 - red, urban areas in 2007 - yellow) in the territory of Lithuania (Gadal 2011, 2012)

The differences in urban dynamics and metropolisation at the regional levels in Lithuania and Latvia on the Via Baltica route can be explained both by the different geographical and economic importance of the cities it traverses (for example, Riga (port and capital city with population of 706413 , Euro City according to Visions and Strategies Around the Baltic Sea (VASAB) classification) and Kaunas (second largest Lithuanian city with population of 306 888, National City according to VASAB classification) (Visions.. 2014)) and by different historically developed overall territorial organisation of the countries. Lithuanian regional planning scheme - the official document adopted during the Soviet period - stimulated even and dispersed regional development of the country's settlement system, allowed the dispersed location of industry in the territory of the country, stimulated the growth and viability of small and middle sized urban settlements, and allowed avoiding hypertrophied growth of the largest urban centres Vilnius and Kaunas (Vanagas, 2003; Burinskiene, 2003). This inheritance of the Soviet period still conditions the more dispersed urban dynamics in the territory of Lithuania compared to Latvia even in very different socio-economic situation and geopolitical orientation.

Impact on environment and landscape. Lithuanian and Latvian cases of urban dynamics on 
the route of Via Baltica represent different patterns of impact on landscape and environment. Urban development concentrated along the transport corridor and related agglomeration processes cause intensive environmental and landscape changes in concentrated limited area and allow preserving natural and agricultural areas in the rest of the region. The dispersed development cause limited but more territorially dispersed impacts. Roads provide specific landscape observation possibilities, thus different patterns of urbanisation in different countries traversed by the Via Baltica route can serve as a source for identity of representing each country or region, which is very important in tourism development. In this case, different urbanisation patterns (for example, dispersed in Lithuania and concentrated in Latvia) together with other landscape features could represent regional diversity. However, in order to use this potential appropriately, integrated and strategic planning of Via Baltica route and its landscape is necessary.

Untapped potential. Despite potential environmental benefits of both urban development concentrated along transport corridor and dispersed urban development, uncoordinated development of Via Baltica may result in both untapped economic, aesthetic and other benefits/ losses: both the chaotic concentration of urbanisation along the route and the failure to manage metropolisation processes can cause the decline of landscape visual quality, loss of local identity and unattractive uniform development. Meanwhile, the failure to use communication and accessibility benefits provided by the road may cause economic losses. For example, the process of metropolisation after the collapse of the USSR to a certain extent concerns large parts of the Lithuanian territory. This major geographic phenomenon changing the face of the territory is rarely integrated in the strategic planning. The Via Baltica is an example of this lack. The Riga-Kaunas corridor should be one of the major axis of territorial development, and not only a space of economic flux disconnected from the territory that it is crossing - a space of transit. This problem is caused by the postSoviet political and societal context and the absence of strategy of territorial development and integrated territorial politics linked to the economic development. There is a dichotomy between the reality of urbanisation and urban development plans implemented by municipalities or the State: hardly regulated urbanisation is guided by the liberalism and the existing theoretical frameworks and methods of planning are out of step with the reality of spatial dynamics of metropolisation and urbanisation and fail to regulate these complex processes. The plans of development of the Via Baltica exactly well reflect this point, e.g. an absence of strategy of development, which could regulate the territorial and economic changes. Investments are limited to some cosmetic and superficial plans as the plan of rest areas within one of the major corridors of development and exchange network of the Baltic region. Moreover, according to D. Giriunaite (2013), today the funding of the Lithuanian tract of Via Baltica is hardly sufficient even for keeping up the current road condition.

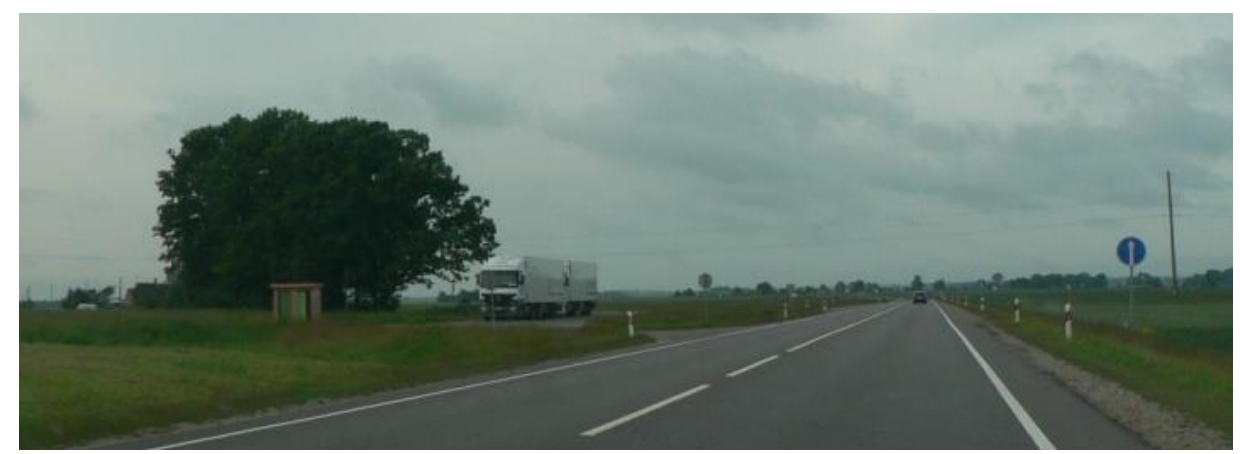

Fig. 6. Poor quality of infrastructure in the Lithuanian tract of Via Baltica in the segment running from Kalvarija via Marijampole to Kaunas. Photograph by I. Grazuleviciute-Vileniske

\section{Via Baltica: local impacts}

P. Abrantes et al. (2005) distinguish development of the services sector and the inner spatial rearrangement of urban areas meaning unregulated urban development and visual/ functional landscape fragmentation, when a multiplicity of functions, which are scarcely compatible with each other, build separate landscape aesthetic worlds of their own (Nohl 2001), as the features of metropolisation. The analysis has demonstrated that these features can be identified at the local (urban settlement) level and that the Lithuanian tract of the Via Baltica transport corridor has a limited impact on the transformation of the urban and territorial structures at the national scale, comparing to the local level. The analysis of urban dynamics of Kaunas, Marijampole, Kalvarija on the route of Via Baltica ha been carried out and demonstrated different patterns of urbanisation in the territory of the country in different localities (Fig. 7.).

The digital remote mapping of the urban evolution of Kaunas region shows the rapid urban expansion after the collapse of USSR and the emergence of road urbanisation since the 2000' within the Via Baltica. It is characterised by the development of services identified by P. Abrantes et al. (2005) and industry - building of new industrial zones (for example, the Free Economic Zone), commercial, logistics zones. The localisation of the city at the 
crossing point between the two major routes of communications and exchange - East-West and North-South - and the industrial heritage from the Soviet period are the main factors of the road impacts on the urbanisation in the context of metropolisation dynamics. Another important feature characteristic to metropolisation - suburbanisation (Gadal 2011a) and related unregulated landscape development and fragmentation - including the emergence of new suburbs and the extension of former Soviet peri-urban areas, for example, Akademija, Domeikava, Garliava, reflecting the changes of lifestyle, the emergence of the middle class, the increase in the level of life, and the strong increase of automobilisation, were also identified.

The impact of Via Baltica on the local development of small and middle size cities, for example Marijampole and Kalvarija, is limited to the emergence of commercial, industrial zones and suburbs in much smaller scale in the framework of metropolisation. As Fig. 7. demonstrates, in the case of smaller urban settlements, the urbanisation is much more road-dependent.

Impact on environment and landscape. Scattered, spot-like, fragmented urban development, especially starting with the economic boom of 2007 2009 , called "the spread of compact urban structures"

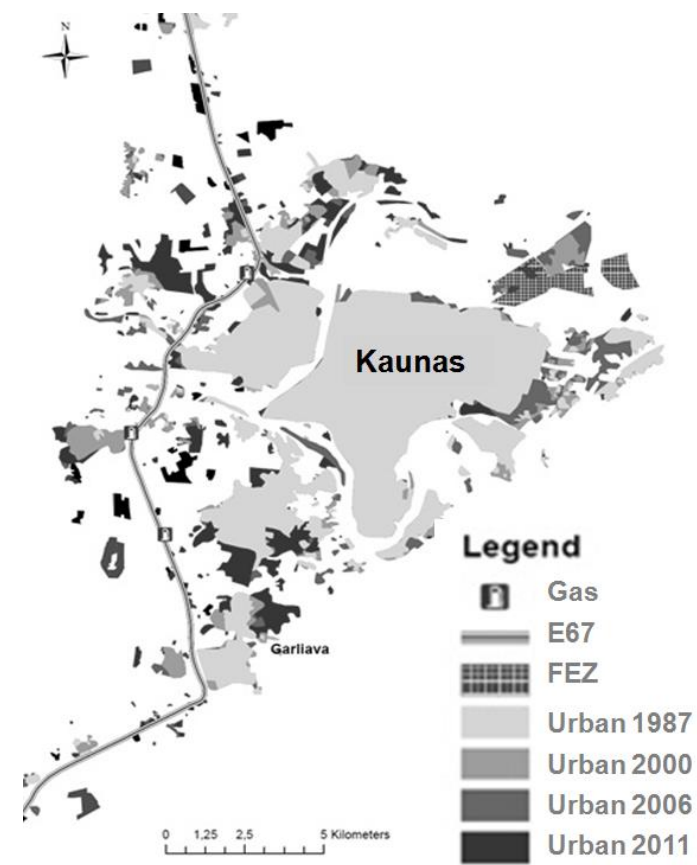

by the Lithuanian researchers and professionals (Bardauskienè and Pakalnis 2012) and visible along the route of Via Baltica in the Fig. 7., especially in the case of Kaunas, has many negative impacts on landscape and environment including inefficient use of resources, the consumption of natural and agricultural land, the change of landscape character (from natural or rural landscape to peri-urban, suburban) and the loss of scenic amenities, the increase in the use of automobile and corresponding pollution etc. D. Bardauskiene and M. Pakalnis (2012) refer to such urban development in rural and natural areas as "worthless suburban landscape, without any urban infrastructure, public spaces and with depredated relief, forest, hydrological systems." Negative impact of such urban dynamics affect rural cultural heritage, which is an inseparable part of landscape quality. For example, the valuable landscape of Versvas rivulet and Linkuva manor site near the Kaunas western bypass (part of the Via Baltica route) was strongly affected by the urbanisation partially induced by the improved accessibility. In some cases such spot-like suburbanisation can be favourable for preserving certain valuable landscape elements; however, in order to achieve this, coordination and foresighted planning, which are absent today, would be needed.

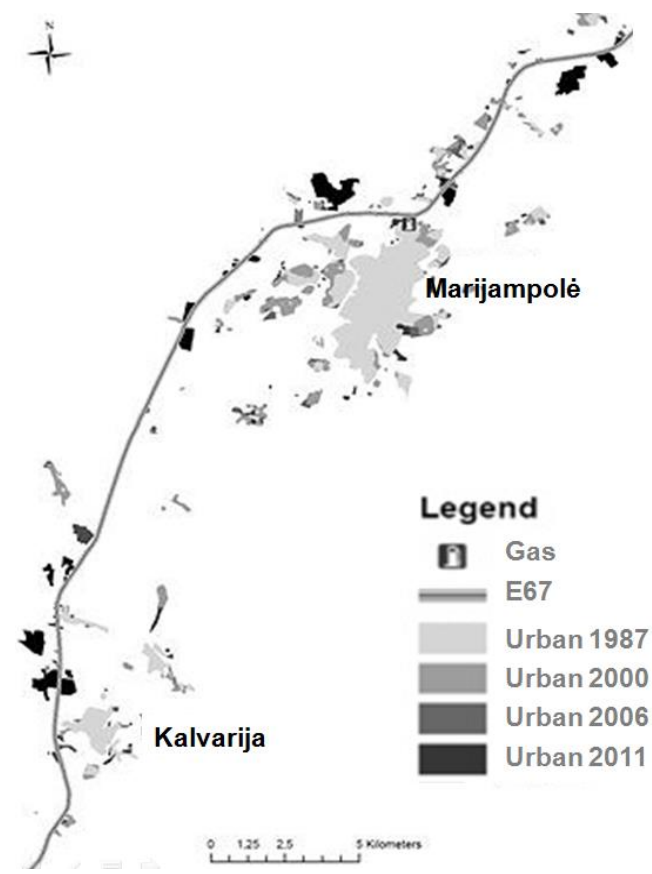

Fig. 7. Urban changes of Kaunas, Marijampole and Klavarija (1987-2011) (Gadal 2012)

Untapped potential. The research demonstrates that non-systematic development of Via Baltica depending on available funding sources (Giriunaite 2013) leaves untapped economic, social, and landscape benefits not only at the regional but also at the local (urban settlement) level. According to E. Berte et al. (2013), linear infrastructure objects including roads, often physically cross areas without providing benefits and services at the local level. They note that in the recent decades because of economic restructuring, technological innovations, and political and economic integration among territories, the contradictions between infrastructure lines and local territories had even increased. The local level interactions between the Via Baltica route and the urban development clearly illustrate such case. Unregulated urban sprawl into rural and natural areas in the zones of influence of large Lithuanian cities has not only negative impact on the environment, landscape, and heritage, but social and economic consequences as well. According D. Bardauskiene and M. Pakalnis (2012), contemporary short-sighted territorial planning just helps "pump up vital forces" from the cities and towns, to occupy 
suburbs with new "suburban villages" and to raise up the infrastructure needs and public services costs. Meanwhile, the Via Baltica traverses such suburban areas just a transport and communication corridor without becoming an axis of coordinated purposeful urban development. Foresighted links between the planning of infrastructure and the planning of local transformations and infrastructure coherency in relation to the ecological system, built areas, and agricultural areas, as E. Berte et al. (2013) note, is a sustainable answer to this problem.

\section{Conclusions}

1. The analysis of the impact of the Via Baltica on the urbanisation in Lithuania demonstrated that the interaction of socio-political and socioeconomic changes, the shifts in the importance of transportation corridors and the dynamics of urbanisation can be mutually interlinked and require integrated research approach. The research methodology based on satellite data, land cover data, and observations on site enabled observation and analysis od spatial changes at the regional and the local geographic levels.

2. The research results have demonstrated certain influence of the Via Baltica on the features of metropolisation distinguished by P. Abrantes et al. (2005) both at the regional and local levels the development of the services sector (local level), the affect on the urban hierarchies and the reinforcement of the higher levels of the urban network (regional level), and the inner spatial rearrangement and fragmentation urban settlements (local level). However, in the territory of Lithuania, if compared with Latvia, the impact is more visible at the local (urban settlement) level.

3. The research has demonstrated that in the absence of comprehensive development policy at the national and regional levels, the general territorial structure of the country has changed little after the collapse of USSR. General urban dynamics in the territory of Lithuania can be characterised by the densification of the built areas of the Soviet period, urban extension and emergence of suburban areas. In this context the Lithuanian tract of Via Baltica - one of the most important routes in the country and in the region - remains just a transport corridor, but not a development axis.

4. The impact of Via Baltica on the local (urban settlement) level urban development works together with the multiplicity of other drivers of urbanisation. Its influence concerns the emergence of commercial, industrial zones and residential suburbs. The lack of foresighted urban planning causes environmental, landscape management, social, and economic problems: landscape fragmentation and degradation, pollution, unsustainable use of resources, additional expenses on infrastructure, poor quality of life etc. and uncoordinated development of the Via Baltica transport corridor and urban areas.

5. Untapped potential of Via Baltica both at the regional and local levels calls for integrated planning of infrastructure and local and regional transformations (including the ecological system, settlement system, and agricultural areas) and viewing the Via Baltica more as development axis not mere transport corridor.

\section{References}

Abrantes P., Bacao F., Lobo V., Tenedorio J. A., 2005. Spatial modeling of metropolization in Portugal. Explanatory analysis of spatial metropolitan patterns. In: $14^{\text {th }}$ European Colloquium on Theoretical and Quantitative Geography, Tomar Portugal, 9-3 September, 2005.

Andersen H. E., Strunk J., Temesgen H., Atwood D., Winterberger $\mathrm{K}$. Using multilevel remote sensing and ground data to estimate forest bi mass resources in remote regions: a case study in the boreal forests of interior Alaska. Canadian Journal of Remote Sensing, 2011, Vol. 37, No. 6, pp. $1-16$.

Antrop M., Van Eetvelde V. Holistic aspects of suburban landscape: visual image interpretation and landscape metrics. Landscape and Urban Planning, 2000, Vol. 50, pp. 43-58. http://dx.doi.org/10.1016/S01692046(00)00079-7

Baltrènas P., Vaitiekuūnas P., Mincevič I. Investigation on the impact of transport exhaust emissions on the air. Journal of Environmental Engineering and Landscape Management, 2004, 12, pp. 3-11.

Bardauskienè, D., Pakalnis, M. Foresighted urban planning. Environmental Research, Engineering and Management, 2012, Vol. 59, pp. 63-72.

Bell S., Penēze Z., Nikodemus O., Montarzino A. 2008. Perception of the Latvian landscape during social and economic transitions. In: Näripea, E., Sarapik, V., Tomberg, J. (Eds.): Place and Location VI, The Research Group of Cultural and Literary Theory, Estonian Literary Museum, Institute of Art History, Estonian Academy of Arts, Estonian Semiotics Association, Tallinn, pp. 239-256.

Berte E., Panagopoulos T., Zanon B. An interpretative model for the management of contemporary cultural landscapes in linear infrastructure projects. Journal of Environmental Engineering and Landscape Management, 2013, Vol. 21, No. 4, pp. 248-262. http://dx.doi.org/10.3846/16486897.2012.745412.

Bhattaa B., Saraswatib S., Bandyopadhyayb D. Urban sprawl measurement from remote sensing data. Applied Geography, 2010, Vol. 30, No. 4, pp. 731-740. http://dx.doi.org/10.1016/j.apgeog.2010.02.002

Burinskienė M. 2003. Subalansuota miestų plètra. Technika, Vilnius.

Ferrier J. P. Postmodern geography or geography of the Third Modernity. Geojournal, 1993, Vol. 31, No. 3, pp. 251-253 
Ferrier J. P. 1998. Antée 2 Le contrat géographique ou l'habitation durable des territoires. Payot, Lausanne. http://dx.doi.org/10.1007/BF00817379

Gadal S. 2003. Identification des formes spatiales de métropolisation par télédétection. Eratosthène, Lausanne. http://dx.doi.org/10.1016/j.envsoft.2013.09.010

Gadal S. 2006. Urban multi-level geographica information satellite generation. In: Campagna, M. (Ed.): GIS for sustainable development. New York, Taylor \& Francis, pp. 313-327.

Gadal S. Urban dynamics in Kaliningrad and Klaipèda coastal regions by remote sensing and GIS. Tiltai, 2010, Vol. 50, No. 1, pp. 101-110.

Gadal S. 2011. Métropolisations, territoires émergents et systèmes géographiques d'informations et de modélisation territorial. Université Paris Diderot Paris 7, Paris.

Gadal S. 2011a. The socio-ecological challenge of metropolised territories: key-notes. In: Ecological Architecture 2011, Kaunas Lithuania,13 October, 2011, pp. $8-12$.

Gadal S. 2012. Riga-Kaunas-Klaipeda road corridors impacts on the urbanization and the spatial structures by multi-level sensors remote sensing (2000-2012). Report of research, Central Baltic Interreg IV. 43p.

Giri C. P. 2012. Remote Sensing of Land Use and Land Cover: Principles and Applications. CRC Press, New York. http://dx.doi.org/10.1201/b11964

Giriūnaite D. 2013. Almost forgotten "Via Baltica" highway is crying out for help, Keliai ir tiltai, Vol. 7. [interactive].

[2014-03-24]

http://www.zurnalastransportas.lt/primirsta-automagistralevia-baltica-saukiasi-pagalbos/?lang=en

Global Land Cover Facility. [interactive]. [2014-08$18]:$

http://glcf.umd.edu/library/guide/techguide_landsat.pdf.

Kovács G.; Spens, K. M. Transport infrastructure in the Baltic States post-EU succession. Journal of Transport Geography, 2006, Vol. 14, No. 6, pp. 426-436. http://dx.doi.org/10.1016/j.jtrangeo.2006.01.003.

Krätke S. Metropolisation of the European economic territory as a consequence of increasing specialisation of urban agglomerations in the knowledge economy. European Planning Studies, 2007, Vol. 15, No. 1, pp. 1-27. http://dx.doi:10.1080/09654310601016424.

Kuemmerle T., Olofsson, P., Chaskovskyy O., Baumann M., Ostapowicz K., Woodcokc C.E., Houghton, R. A., Hostert P., Keeton W. S., Radeloff V. C. Post-Soviet farmland abandonment, forest recovery, and carbon sequestration in western Ukraine. Global Change Biology, 2010, Vol. 17, No. 3, pp. 1335-1349 http://dx.doi.org/10.1111/j.1365-2486.2010.02333.x

Lama A., Smirnovs J., Naudzuns J. Road traffic safety in the Baltic States. Baltic Journal of Road and Bridge Engineering, 2006, No. 1, pp. 63-68.

Manchanda M. I., Iyes H. S., Singht,H. S., Prasad J.
Multilevel land use surveys using remote sensing techniques. Journal of Indian Society of Photointerpreation and Remote Sensing, 1983, Vol. 11, No. 3, pp. 67-74

Mas J.F., Paegelow M., Camacho Olmedo M. T., Houet $\mathrm{T}$. Inductive pattern-based land use/cover change models: A comparison of four software packages. Environmental Modelling \& Software, 2014, Vol. 51, No. 1, pp. 94-111.

Melnikas B. Integral European cultural space and regional development: transition processes in the Baltic and other CEE countries. Transformations in Business \& Economics, 2005, Vol. 14, No. 1, pp. 87-105.

Murzyn-Kupisz M., Gwosdz K. The changing identity of the Central European city: the case of Katowice. Journal of Historical Geography, 2011, Vol. 37, pp. 113-126. http://dx.doi.org/10.1016/j.jhg.2010.04.001

National Oceanic And Atmospheric Administration. [interactive].

[2014-08-18]: https://catalog.data.gov/harvest/object/e84ef28f-7935-4ca2b9c7-7a77cb156c4c/html.

Nigam R. K. Application of remote sensing and Geographical Information system for land use / land cover mapping and change detection in the rural urban fringe area of Enschede city, the Netherlands. International Archives of Photogrammetry and Remote Sensing, 2000, Vol. 32, pp. 993-997.

Nohl W. Sustainable landscape use and aesthetic perception - preliminary reflections on future landscape aesthetics. Landscape and Urban Planning, 2001, Vol. 54, pp. 223-237. http://dx.doi.org/10.1016/S01692046(01)00138-4

Ode A., Tveit M.S., Fry G. Capturing landscape visual character using indicators: touching base with landscape aesthetic theory. Landscape Research, 2008, Vol. 33, No. 1, pp. 89-117. http://dx.doi.org/10.1080/01426390701773854

Ojala L., Quieroz C. 2003. Freight transport restructuring in the Baltic States, in Transportation and public policy 2003. Transportation research board, National research council, Washington, pp. 77-81.

Polanska, D. Decline and revitalization in postcommunist urban context: a case of the Polish city Gdansk. Communist and Post-Communist Studies, 2008, Vol. 41, pp. 359-374. http://dx.doi.org/10.1016/j.postcomstud.2008.06.002

Ramachandra T. V., Bharath S., Bharath A. Spatiotemporal dynamics along the terrain gradient of diverse landscape. Journal of Environmental Engineering and Landscape Management, 2013, Vol. 22, No. 1, pp. 50-63.

http://dx.doi:10.3846/16486897.2013.808639.

Rodzik E., Quieroz C. 2001. Road financing and management in the Baltic States. In: Transportation and public policy 2001, Transportation research board, National research council, Washington, pp. 12-18.

Scott J.W., Kuhn M. Urban change and urban development strategies in Central East Europe: a selective assessment of events since 1989. European Planning Studies, 2012, Vol. 20, No. 7, pp. 1093-1109. http://dx.doi.org/10.1080/09654313.2012.674345 
Serry A. 2010. Transport durable et développement dans les Etats Baltes: l'exemple Lituanien. In: Conference proceedings of transport et développement des territoires, Le Havre, 8-10 September.

Short, N. M. 2005. The "multi" approach to applied remote sensing: multiplatforms and multilevels. [interactive]. [2014-08-18]:

http://fas.org/irp/imint/docs/rst/Sect13/Sect13_4a.html.

Sohn H. G., Kim G. H., Heo J. Road change detection algorithms in remote sensing environment. Lecture Notes in Computer Science, 2005, Vol. 3645, pp. 821-830. http://dx.doi.org/10.1007/11538356_85

Vanagas J. 2003. Miesto teorija. Vilnius.

Visions and Strategies Around the Baltic Sea (VASAB) [interactive], [2014-03-24]: http://www.vasab.org/

Wang X., Zhao H., Fang B., Fu G., Wang W. 2008. The development of road information extraction from remote sensing images. In: Proceedings of SPIE, Vol. 7285, No. 1.

Wheeler D. J., Ridd M. K. A geographic information system for resource managers based on multi-level remote sensing data. In: ASP, Annual Meeting, 51st, Washington, DC, March 10-15, 1985, Technical Papers, Vol. 2 (A8646051 22-43), Falls Church, VA, American Society of Photogrammetry, 1985, pp. 528-537.

Wu L., Hu Y. A. A Survey of automatic road extraction from remote sensing images. Acta Automatica Sinica, 2010, Vol. 36, No. 7, pp. 912-922. http://dx.doi.org/10.3724/SP.J.1004.2010.00912
Zielinski B., Iwanowski, M. Morphology-based method for reconstruction of invisible road parts on remote sensing imagery and digitized maps. Advances in Intelligent and Soft Computing, 2011, Vol. 95, No. 4, pp. 411-420. http://dx.doi.org/10.1007/978-3-642-20320-6_43

Prof. habil. dr. Sébastien Gadal - Aix-Marseille Université, CNRS, ESPACE, UMR 7300.

Main research areas: metropolisation, territorial development, socio-environmental impacts, development of urban spatial monitoring systems by remote sensing, geographic information systems, and simulation.

Address: 29 avenue Robert Schuman, 13621 Aixen-Provence cedex 1, France

E-mail: $\quad$ sebastien.gadal@univ-amu.fr

Assoc. prof. Indrė Gražulevičiūtè-Vileniškė Department of Architecture and Urbanism, Faculty of Civil Engineering and Architecture, Kaunas University of Technology.

Main research areas: preservation and management of built heritage, application of principles of sustainability to architecture and landscape, ruralurban interface, rurban landscapes.

Address: $\quad$ Studentu st. 48, LT-51367 Kaunas, Lithuania

Tel.: $\quad+37037451546$

Fax: $\quad+37037451546$

E-mail: $\quad$ indre.grazuleviciute@ktu.lt 


\title{
Via Baltica ịtakos urbanizacijai Lietuvoje daugiapakopio nuotolinio stebẻjimo tyrimas
}

\author{
Sébastien Gadal ${ }^{1}$ ir Indrẻ Gražulevičiūtè-Vilenišk $\dot{e}^{2}$ \\ ${ }^{I}$ Aix-Marseille universitetas, CNRS, Marselis, Prancūzija \\ ${ }^{2}$ Kauno technologijos universitetas, Architektūros ir urbanistikos fakultetas, Kaunas, Lietuva
}

(gauta 2014 m. birželio mèn., priimtas spaudai 2014 m. rugpjūčio mèn.)

Suirus Sovietų sajungai, Baltijos šalyse, taip pat ir Lietuvoje, radikaliai keitėsi teritorijų ir urbanizacijos dinamika. Teritoriniai pokyčiai apima ekstensyvią miestų plètrą, suburbanizaciją, urbanizuotų teritorijų sutankinimą. Via Baltica magistralès statyba ir atnaujinimas yra vienas iš svarbiausių teritorinès ir ekonominès Baltijos šalių integracijos į Europos sajungą veiksnių. Nuo 2000-ųjų vidurio Via Baltica buvo ir vis dar yra urbanizacijos, lemiamos pagerejusio susisiekimo ir gyventojų automobilizacijos, variklis. Tyrimo tikslas buvo išanalizuoti urbanizacijos dinamiką Lietuvoje Via Baltica ịtakos zonoje vietiniame ir regioniniame kontekste. Tyrimas atskleidè, kad Via Baltica itaka urbanizacijai, remiantis nuotolinio stebejjimo tyrimais, yra žymesnè vietiniu lygiu. Buvo prieita išvados, kad šis transporto koridorius turètų būti daugiau laikomas bendruosius urbanizacijos ir metropolizacijos procesus Lietuvoje ir Baltijos šalyse struktūrinančiu teritoriniu vektoriumi. 